\title{
PENENTUAN PROFIL BIOAUTOGRAFI DAN AKTIVITAS ANTIOKSIDAN EKSTRAK ETANOL DAUN BIDARA (Ziziphus mauritiana Auct. non Lamk.) DENGAN METODE PENANGKAPAN RADIKAL DPPH
}

\author{
Samirana, P. O. ${ }^{1}$, Taradipta, I. D. M. R. ${ }^{1}$, Leliqia, N. P. E. ${ }^{1}$ \\ ${ }^{1}$ Jurusan Farmasi Fakultas Matematika dan Ilmu Pengetahuan Alam Universitas Udayana \\ Korespondensi: Putu Oka Samirana \\ Jurusan Farmasi Fakultas Matematika dan Ilmu Pengetahuan Alam Universitas Udayana \\ Jalan Kampus Unud-Jimbaran, Jimbaran-Bali, Indonesia 80364 Telp/Fax: 0361-703837
}

Email: oka_samirana@unud.ac.id

\begin{abstract}
ABSTRAK
Bidara atau yang dikenal dengan bahasa latin Ziziphus mauritiana Lam. telah diketahui memiliki beberapa aktivitas, diantaranya adalah aktivitas hepatoprotektif, antidiabetes, imunomodulator dan antioksidan. Selain itu terdapat penelitian yang melaporkan bahwa ekstrak etanol daun Z. mauritiana memiliki aktivitas adaptogenik. Suatu teori menyatakan bahwa aktivitas antioksidan berkontribusi terhadap aktivitas adaptogenik yang dimiliki oleh suatu tanaman. Sehingga pada penelitian ini akan dilakukan uji antioksidan ekstrak etanol daun Z. mauritiana serta penentuan profil bioautografi dengan KLT.

Hasil menunjukkan bahwa ekstrak etanol daun Z. mauritiana memiliki aktivitas antioksidan dengan $\mathrm{IC}_{50}$ sebesar $59,52 \pm 1,2 \mu \mathrm{g} / \mathrm{mL}$. Dibandingkan dengan vitamin $\mathrm{C}$ yang memiliki nilai $\mathrm{IC}_{50}$ sebesar 2,73 $\pm 0,05 \mu \mathrm{g} / \mathrm{mL}$, ekstrak etanol daun Z. mauritiana memiliki aktivitas antioksidan lebih rendah. Hasil profil bioautografi menunjukkan bercak ke-4 dan 10 pada uji flavonoid, bercak ke-12 dan 15 pada uji saponin serta bercak ke-10 pada uji triterpenoid diduga memiliki aktivitas antioksidan.
\end{abstract}

Kata Kunci: $\quad$ Ziziphus mauritiana, Daun, Ekstrak Etanol, Swimming Endurance Test, Adaptogenik

\begin{abstract}
Bidara or known by the Latin Ziziphus mauritiana Lam. has been known to have several activities, including hepatoprotective activity, antidiabetes, immunomodulators, and antioxidants. In addition, there are studies that report that the ethanol extract of $\mathrm{Z}$. mauritiana leaves has adaptogenic activity. A theory suggests that antioxidant activity contributes to the adaptogenic activity possessed by a plant. So in this research will be tested the antioxidant extract ethanol leaves Z. mauritiana and the determination of bioautography profile with TLC.

The results showed that ethanol extract of Z. mauritiana leaf had antioxidant activity with IC50 of 59,52 $\pm 1,2 \mu \mathrm{g} / \mathrm{mL}$. Compared with vitamin $\mathrm{C}$ which has an IC50 value of $2.73 \pm 0.05 \mu \mathrm{g} / \mathrm{mL}$, the ethanol extract of Z. mauritiana leaves has lower antioxidant activity. The bioautographic profile results show the 4th and 10th spots on the flavonoid test, the 12th and 15th spots on the saponin test and the 10th spot on the triterpenoid test alleged to have antioxidant activity.
\end{abstract}

Keywords: Ziziphus mauritiana, Leaf, Ethanolic Extract, Swimming Endurance Test, Adaptogenic 


\section{PENDAHULUAN}

Bidara atau yang dikenal dengan bahasa latin Ziziphus mauritiana Lam. telah diketahui memiliki beberapa aktivitas, diantaranya adalah aktivitas hepatoprotektif, antidiabetes, imunomodulator dan antioksidan (Dahiru et al., 2007; Bhatia et al., 2010; Mishra and Bhatia, 2010; Perumal et al., 2012). Selain itu Samirana dkk. (2015) melaporkan bahwa ekstrak etanol daun Z. mauritiana memiliki aktivitas adaptogenik.

Aktivitas adaptogenik dari suatu tanaman didukung oleh beberapa golongan senyawa tertentu. Panossian et al. (1999) berpendapat bahwa senyawa dalam tanaman yang memiliki sifat adaptogenik terdiri dari tiga golongan senyawa yaitu triterpen, fenilpropanoid dan oksilipin. Senyawa golongan fenol termasuk fenilpropanoid pada tanaman adaptogen (misalnya flavonoid dan lignan) disintesis dari tirosin, secara struktural mirip dengan katekolamin (Vinod and Shivakumar, 2012; Panossian and Wikman, 2010). Senyawa golongan fenilpropanoid memiliki aktivitas antioksidan (Korkina, 2007), sehingga kemungkinan yang berkontribusi terhadap aktivitas adaptogenik adalah senyawa antioksidan.

Beberapa penelitian sebelumnya telah melaporkan bahwa daun $Z$. mauritiana memiliki aktivitas antioksidan. Perumal et al. (2012) melaporkan ekstrak metanol daun dari Z. mauritiana diketahui memiliki aktivitas penangkapan radikal bebas DPPH dengan nilai $\mathrm{IC}_{50}$ sebesar $21,40 \pm 0,15 \mu \mathrm{g} / \mathrm{mL}$ bila dibandingkan dengan standar BHT yang memiliki nilai $\mathrm{IC}_{50}$ sebesar $18,50 \pm 0,19 \mu \mathrm{g} / \mathrm{mL}$. Abalaka et al. (2011) juga melaporkan ekstrak etanol dan ekstrak heksan daun Z. mauritiana memiliki aktivitas penangkapan radikal DPPH dengan nilai $\mathrm{IC}_{50}$ masing-masing sebesar $101,02 \mu \mathrm{g} / \mathrm{ml}$ dan $124,21 \mu \mathrm{g} / \mathrm{mL} \quad$ serta dibandingkan dengan standar asam askorbat yang memiliki nilai $\mathrm{IC}_{50}$ sebesar $78,12 \mu \mathrm{g} / \mathrm{mL}$.

Walaupun telah dilaporkan memiliki aktivitas antioksidan, namun data tersebut belum dapat dijadikan dasar untuk aktivitas antioksidan, mengingat kondisi tempat tumbuh tanaman yang menyebabkan perbedaan kandungan kimia yang dimiliki tumbuhan (Kardono, 2003). Berdasarkan hal tersebut maka dilakukan uji konfirmasi aktivitas antioksidan ekstrak etanol dengan metode penangkapan radikal DPPH. Selain itu juga dilakukan penentuan profil bioautografi.

\section{BAHAN DAN METODE}

2.1 Bahan Penelitian

Daun Z. mauritiana dari daerah Bukit Jimbaran, Kabupaten Badung, Bali, etanol $96 \%$, plat silika gel $\mathrm{GF}_{254}$ (Merck), DPPH (2,2difenil-1-pikrilhidrazil), bahan pelarut seperti amonia, etil asetat, butanol, asam asetat, kloroform, metanol dan toluen yang masingmasing berderajat pro analisis. Selain itu, digunakan juga pelarut yang berderajat teknis yaitu aquadest.

\subsection{Alat Penelitian}

Toples kaca, blender, sudip, sendok tanduk, pisau, alat gelas, timbangan analitik $\left(\mathrm{AND}^{\circledR}\right)$, kertas saring, tangki silinder gelas berukuran $30 \times 10 \mathrm{~cm}$, Rotary evaporator $\left(\right.$ Eyela $\left.^{\circledR}\right)$ bejana pengembang (CAMAG) dan lampu UV (CAMAG)

\subsection{Prosedur Penelitian}

\subsubsection{Ekstraksi}

Serbuk daun Z.mauritiana kering sebanyak $1 \mathrm{~kg}$ dimaserasi dengan 7,5 L pelarut etanol $96 \%$ selama $\pm 3 \times 24$ jam dengan dilakukanpengadukansesekali. Ketika proses telah selesai dilakukanpenyaringan. Residu dimaserasi kembali dengan $5 \mathrm{~L}$ etanol. Remaserasi dilakukan sebanyak 2 kali selama \pm $2 \times 24$ jam. Ekstrak hasil maserasi atau filtrat yang dihasilkan ditampung menjadi satu dan diuapkan dengan menggunakan alat Rotary evaporator pada suhu $45-50^{\circ} \mathrm{C}$, sehingga diperoleh ekstrak kental.

\subsubsection{Uji Konfirmasi Aktivitas Antioksidan}

Aktivitas antioksidan diuji secara in vitro dengan mengukur kemampuan sampel menangkap radikal DPPH (2,2-difenil-1pikrilhidrazil). Sampel uji (ekstrak etanol daun Z. mauritiana) dilarutkan dan diencerkan dengan metanol hingga diperoleh beberapa seri konsentrasi. Kontrol positif yang digunakan adalah vitamin $\mathrm{C}$, dibuat dengan konsentrasi 1 $\mathrm{mg} / \mathrm{mL}$ dalam metanol. Larutan DPPH disiapkan dengan menimbang $15,8 \mathrm{mg}$ serbuk DPPH, kemudian dilarutkan dalam labu takar $100 \mathrm{~mL}$ dengan metanol hingga tanda batas.

Sebelum dilakukan pengukuran aktivitas penangkapan radikal bebas DPPH, terlebih dahulu dilakukan penentuan panjang gelombang maksimum DPPH. Sebanyak 1,0 $\mathrm{mL}$ DPPH 0,4 mM ditambahkan dengan $4 \mathrm{~mL}$ metanol, kemudian campuran divorteks dan 
dibiarkan selama 30 menit dalam ruang gelap. Campuran larutan ini diukur absorbansinya menggunakan spektrofotometer UV-Vis pada rentang panjang gelombang $450-550 \mathrm{~nm}$. Nilai panjang gelombang maksimal diamati dengan melihat nilai absorbansi tertinggi pada satu titik panjang gelombang.

Uji penangkapan radikal bebas DPPH dilakukan sesuai dengan metode yang diajukan oleh Kikuzaki et al. (2002). Sejumlah sampel tertentu ditambahkan dengan 1,0 ml DPPH 0,4 $\mathrm{mM}$ dan ditambahkan metanol sampai volume $5 \mathrm{~mL}$. Campuran tersebut selanjutnya divorteks dan dibiarkan selama 30 menit. Campuran selanjutnya diukur absorbansinya pada panjang gelombang $515 \mathrm{~nm}$ dengan blanko yang digunakan adalah metanol. Pengukuran absorbansi juga dilakukan terhadap kontrol yang terdiri atas $1,0 \mathrm{ml}$ DPPH dan $4,0 \mathrm{ml}$ metanol. Senyawa pembanding digunakan dalam uji penangkapan radikal bebas DPPH ini adalah Vitamin $C$ yang sudah diketahui sebagai antioksidan. Persentase penangkapan radikal bebas oleh sampel dapat dihitung dengan persamaan 1 .

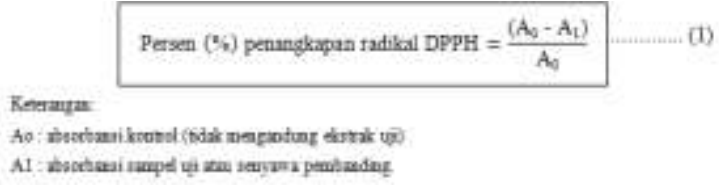

Parameter yang digunakan untuk aktivitas antioksidan dengan metode penangkapan radikal DPPH ini adalah $\mathrm{IC}_{50}$, yaitu konsentrasi senyawa uji yang dibutuhkan untuk menangkap radikal bebas DPPH sebanyak $50 \%$. Nilai $\mathrm{IC}_{50}$ diperoleh dengan membuat suatu persamaan regresi linier yang menyatakan hubungan konsentrasi senyawa uji dengan persen aktivitas penangkapan radikal bebas DPPH. Semakin kecil nilai dari $\mathrm{IC}_{50}$, maka semakin kuat senyawa uji tersebut sebagai penangkap radikal DPPH.

\subsubsection{Uji Antioksidan dengan KLT}

Bioautografi.

Fase diam yang digunakan adalah silika gel $\mathrm{GF}_{254}$ dan fase gerak yang digunakan tergantung dari golongan senyawa kimia yang akan diidentifikasi dengan KLT. Fase gerak yang digunakan dapat dilihat pada tabel 1 .

Chamber dijenuhkan dengan fase gerak selama 30 menit. Larutan uji dibuat dengan cara sejumlah ekstrak kental daun Z. mauritiana Lam. dilarutkan dalam metanol. Sebanyak 10 $\mu \mathrm{L}$ larutan uji ditotolkan pada plat silika gel
$\mathrm{GF}_{254}$. Plat KLT dielusi sampai tanda batas dalam bejana pengembang yang telah dijenuhkan. Setelah dielusi, plat KLT dikeluarkan dari bejana pengembang dan dikeringkan. Plat kemudian diamati pada sinar UV dengan panjang gelombang 254 dan 366 nm. Diamati spot dan warna yang dihasilkan. $\mathrm{Rf}$ dari masing-masing spot dihitung.

Tabel 1. Sistem Fase Gerak yang Digunakan untuk KLT-Densitometri (Harborne, 1987; Reich and Blatter, 2003; Markham, 1988).

\begin{tabular}{ll}
\hline $\begin{array}{l}\text { Golongan } \\
\text { Senyawa }\end{array}$ & Sistem Fase Gerak \\
\hline Flavonoid & $\begin{array}{l}\text { Butanol: Asam Asetat: Air } \\
(4: 1: 5 \mathrm{v} / \mathrm{v})\end{array}$ \\
Triterpenoid & $\begin{array}{l}\text { Kloroform: Metanol (20:1 } \\
\text { v/v) }\end{array}$ \\
Saponin & $\begin{array}{l}\text { Kloroform: Metanol: Air } \\
(70: 30: 4 \mathrm{v} / \mathrm{v})\end{array}$ \\
& $\begin{array}{l}\text { Toluen: Etil Asetat: Amonia } \\
(80: 10: 10 \mathrm{v} / \mathrm{v})\end{array}$ \\
\hline
\end{tabular}

Selanjutnya plat disemprot dengan DPPH 0,4 mM. Diamati adanya perubahan warna spot selama kurang lebih 10 menit. Hasil positif adanya penangkapan radikal DPPH oleh senyawa antioksidan ditandai dengan perubahan area spot yang semula ungu (setelah disemprot DPPH) menjadi warna kuning. Spotspot yang mengalami perubahan warna dicatat nilai Rf-nya.

\section{HASIL}

\subsection{Ekstraksi}

Ekstrak kental yang diperoleh dari maserasi dengan pelarut etanol $96 \%$ sebanyak 61,42 gram dengan rendemen $6,14 \% \mathrm{~b} / \mathrm{b}$.

\subsection{Uji Antioksidan dengan KLT Bioautografi. \\ Hasil uji antioksidan dengan KLT Bioautografi dapat dilihat pada gambar 1 .}

\section{PEMBAHASAN}

Dari hasil uji aktivitas penangkapan radikal DPPH, ekstrak etanol daun $Z$. mauritiana memiliki nilai $\mathrm{IC}_{50}$ sebesar 59,52 \pm $1,2 \mu \mathrm{g} / \mathrm{mL}$ sedangkan vitamin $\mathrm{C}$ memiliki nilai $\mathrm{IC}_{50}$ sebesar $2,73 \pm 0,05 \mu \mathrm{g} / \mathrm{mL}$. Nilai $\mathrm{IC}_{50}$ kemudian dianalisis dengan Independent T-test dengan taraf kepercayaan $95 \%$. Hasil analisis 
Samirana dkk.

Jurnal Farmasi Udayana, Vol. 6, No.2, Tahun 2017, 18-22

statistik dengan Independent T-test menunjukkan nilai $\mathrm{IC}_{50}$ ekstrak etanol daun $Z$. mauritiana memiliki nilai yang lebih tinggi secara signifikan $(\mathrm{p}<0,05)$ dibandingkan dengan nilai $\mathrm{IC}_{50}$ vitamin C. Dengan demikian ekstrak etanol daun Z. mauritiana memiliki aktivitas antioksidan lebih rendah secara signifikan $(\mathrm{p}<0,05)$ dibandingkan dengan vitamin $C$, karena untuk menghambat 50 persen dari kadar radikal DPPH dibutuhkan konsentrasi ekstrak etanol daun Z. mauritiana yang lebih banyak dibandingkan dengan vitamin C.

Pada penentuan profil bioautografi dengan KLT bertujuan untuk memperkirakan golongan senyawa apakah dalam ekstrak etanol Z. mauritiana yang kemungkinan memiliki aktivitas antioksidan.

Berdasarkan Gambar 1., Pada uji golongan senyawa flavonoid dengan KLT, bercak ke-4 dan 10 menghasilkan warna kuning, dimana senyawa antioksidan jika bereaksi dengan DPPH akan terbentuk warna kuning terang. Berdasarkan hasil tersebut golongan senyawa flavonoid yang terdapat pada bercak ke-4 diduga memiliki aktivitas antioksidan. Golongan senyawa flavonoid memiliki aktivitas antioksidan dengan mekanisme mendonorkan atom hidrogen kepada radikal bebas (Brewer, 2011).

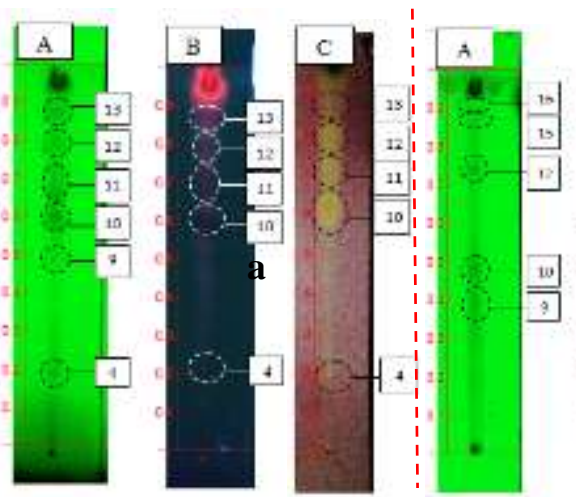

A

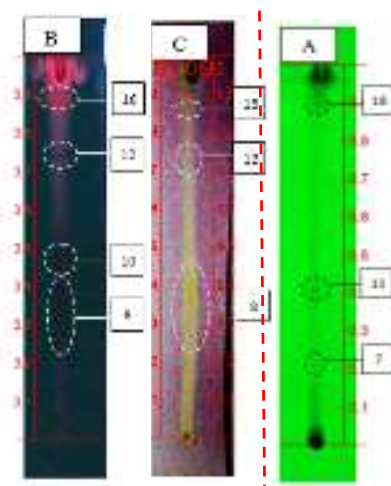

B

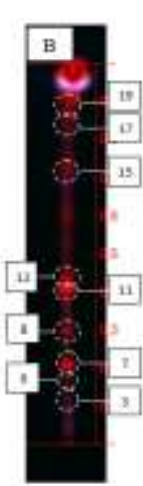

C
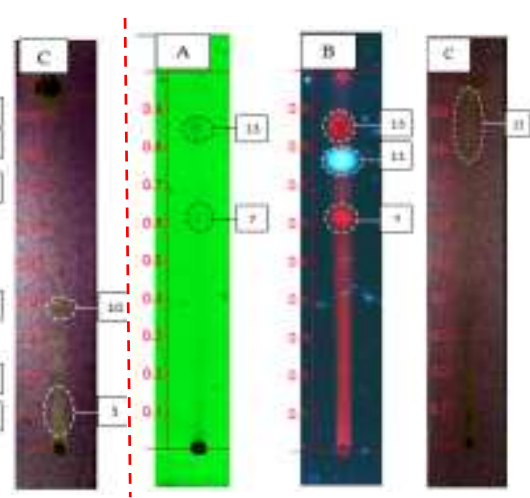

D

Gambar 1. Profil KLT uji flavonoid (a), Saponin (b), Triterpenoid (c) dan Alkaloid (d) ekstrak etanol daun Z. mauritiana di bawah sinar UV $254 \mathrm{~nm}$ (A), $366 \mathrm{~nm}$ (B) dan direaksikan dengan DPPH (C). 


\section{KESIMPULAN}

Ekstrak etanol daun Z. mauritiana memiliki aktivitas antioksidan dengan $\mathrm{IC}_{50}$ sebesar 59,52 $\pm 1,2 \mu \mathrm{g} / \mathrm{mL}$. Dibandingkan dengan vitamin $\mathrm{C}$ yang memiliki nilai $\mathrm{IC}_{50}$ sebesar 2,73 $\pm 0,05 \mu \mathrm{g} / \mathrm{mL}$, ekstrak etanol daun Z. mauritiana memiliki aktivitas antioksidan lebih rendah. Hasil profil bioautografi menunjukkan bercak ke-4 dan 10 pada uji flavonoid, bercak ke-12 dan 15 pada uji saponin serta bercak ke-10 pada uji triterpenoid diduga memiliki aktivitas antioksidan.

\section{DAFTAR PUSTAKA}

Akinpelu, B.A., O.A. Igbeneghu, A.I. Awotunde, E.O. Iwalewa and O.O. Oyedapo. 2014. Antioxidant and Antibacterial Activities of Saponin Fractions of Erythropheleum suaveolens (Guill. and Perri.) Stem Bark Extract. Scientific Research and Essay. Vol. 9 (18): 826-833.

Bhatia A. and M. Tulica. 2010. Hypoglycemic Activity of Ziziphus mauritiana Aqueous Ethanol Seed Extract in Alloxan-induced Diabetic Mice. Pharmaceutical Biology. Vol. 48 (6): 604-610.

Brewer, M.S. 2011. Natural Antioxidants: Sources, Compounds, Mechanisms of Action, and Potential Applications. Comprehensive Reviews in Food Science and Food Safety. Vol. 10: 221247.

Dahiru, D. and O. Obidoa. 2007. Pretreatment of Albino Rats with Aqueous Leaf Extract of Ziziphus mauritiana Protects Against Alcohol Induced Liver Damage. Tropical Journal of Pharmaceutical Research. Vol. 6 (2): 705-710.

Grace-Lynn, C., I. Darah, Y. Chen, L.Y. Latha, S.L. Jothy and S. Sasidharan. 2012. In Vitro Antioxidant Activity Potential of Lantadene A, a Pentacyclic Triterpenoid of Lantana Plants. Molecules. Vol. 17: 11185-11198.

Harborne, J.B. 1987. Metode Fitokimia: Penuntun Cara Modern Menganalisis
Tumbuhan. Terbitan Kedua. Bandung: Penerbit ITB. Hal. 127.

Kardono, L. B. S. 2003. Kajian Kandungan Kimia Mahkota Dewa (Phaleria marcocarpa). Jakarta: Pusat Penelitian dan Pengembangan Farmasi dan Obat Tradisional Badan Penelitian dan Pengembangan Kesehatan. Hal. 56.

Kikuzaki, H., Hisamoto, M., Hirose, K., Akiyama, K., and Taniguchi, H., 2002. Antioxidants Properties of Ferulic Acid and Its Related Compounds. J. Agric. Food Chem., Vol. 50, Page 2161-2168.

Korkina, L.G. 2007. Phenylpropanoids as Natural Occuring Antioxidants: from Plant Defense to Human Health. Cellular and Molecular Biology. Vol. 53 (1): 15-25.

Markham, K.R. 1988. Cara Mengidentifikasi Flavonoid. Bandung: Penerbit ITB. Hal. 20-26.

Mishra, T. and A. Bhatia. 2010. Augmentation of Expression of Immunocytes' Function by Seed Extract of Ziziphus mauritiana (Lamk.). J. Ethnopharmacol. Vol. 127 (2): 341-5.

Panossian, A., G. Wikman and H. Wagner. 1999. Plant Adaptogens III.* Earlier and More Recent Aspects and Concepts on Their Mode of Action. Phytomedicine. Vol. 6 (4): 287-300.

Panossian, A. and G. Wikman. 2010. Review Effects of Adaptogens on the Central Nervous System and the Molecular Mechanisms Associated with Their Stress-Protective Activity. Pharmaceuticals. Vol. 3: 188-224.

Perumal, S., R. Mahmud, S.P. Piaru, L.W. Cai and S. Ramanathan. 2012. Potential Antiradical Activity and Cytotoxycity Assesment of Ziziphusmauritiana and Syzygium polyanthum. Int.J.Pharmacol. Vol.8(6): 535-541.

Vinod, S. P. and H. Shivakumar. 2012. A Current Status of Adaptogens: Natural Remedy to Stress. Asian Pacific Journal of Tropical Disease. S480S490. 